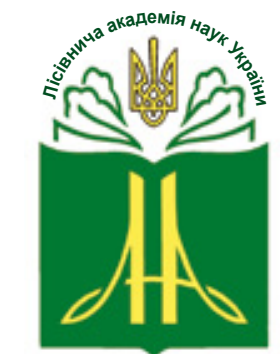

Forestry Academy of Sciences of Ukraine

Наукові праці Лісівничої академії наук України Proceedings of the Forestry Academy of Sciences of Ukraine

http://fasu.nltu.edu.ua

https://doi.org/10.15421/411939

Article received 2019.08.05

Article accepted 2019.12.26
ISSN 1991-606X print

ISSN 2616-5015 online

@ $\square$ Correspondence author

Ihor Soloviy

soloviy@yahoo.co.uk

General Chuprynka st., 103, Lviv, 79057, Ukraine

УДК[[662.818.6:620.92]-029:32](477)

\title{
Використання паливної деревини у фокусі уваги біоенергетичної політики України
}

\author{
І.П. Соловій', М.С. Кафлик², П.Б. Дубневич³
}

Деревне біопаливо є одним із важливих джерел альтернативної енергії в Україні. Водночас деревна біомаса є одним із найдешевших енергетичних ресурсів. Доведено, щэо ії обсяги у є достатніми для забезпечення енергетичних потреб населення. Проте значний потениійно доступний обсяг деревної біомаси в Україні не використовується для енергетичних потреб, зокрема, залишки деревини на лісосіках. Використання відходів заготівлі та обробки деревини як палива є екологічно та економічно ефективним рішенням. Обгрунтовано доцільність запровадження біоенергетичної політики, що регулюватиме прочес вторинного використання деревини. В Украйні не прийняті законодавчі норми та положення, які регулюють біоенергетичну сферу, крім «Енергетичної стратегії України до 2035 року». Використання деревної біомаси в енергетичних цілях не регулюється чіткою та прозорою біоенергетичною політикою і набором відповідних інструментів. Раціональне використання потенціалу відходів деревини з позицій економіки замкненого ииклу може зробити вагомий внесок у вирішення енергетичної проблеми в Україні. Енергетична стратегія України на період до 2035 р. розглядає деревну біомасу як один із варіантів отримання паливної енергії, але не описує дії та заходи, безпосередньо спрямовані на отримання цьвого виду енергії. Законодавча база Украӥни не розглядає достатньо детально деревну біомасу як самостійний вид палива. Розвиток біоенергетики охоплює питання отримання енергії з лісосічних відходів, відходів деревообробки та неліквідних залишків, а також енергетичних плантацій. Формування біоенергетичної політики та регіональних стратегій сталого розвитку біоенергетики на основі оцінювання потениіалу деревної біомаси є основним завданням біоенергетичного напряму в рамках лісового сектору.

Ключові слова: деревна біомаса; біопаливо; відновна енергетика; біоенергетичний потенціал; лісовий сектор; біоенергетична політика.

Вступ. Необмежене прогресуюче використання невідновних видів палива зумовило виникнення цілої низки проблем: зміни клімату, забруднення довкілля, зменшення біорізноманіття тощо. Одним із шляхів їх вирішення є перехід до використання енергії, виробництво якої завдає якомога меншої шкоди довкіллю. В сучасних умовах через зростання вартості невідновних енергетичних ресурсів, в т.ч. природного газу, альтернативні джерела енергії набувають все більшої популярності. Основною пе-

\footnotetext{
Соловій Ігор Павлович - академік Лісівничої академії наук України, віце-президент ЛАН України, доктор економічних наук, професор кафедри екологічної економіки. Національний лісотехнічний університет України, вул. Генерала Чупринки, 103, м. Львів, 79057, Україна. Тел.: 032-287-03-88, +38-097-284-08-81. E-mail: soloviy@yahoo.co.uk ORCID: https://orcid.org/0000-0001-5885-6264

2 Кафлик Марія Степанівна - аспірант кафедри екологічної економіки. Національний лісотехнічний університет України, вул. Генерала Чупринки, 103, м. Львів, 79057, Україна. Тел.: +38-097-443-13-95. E-mail: andruschakevich1994@i.ua ORCID: https://orcid.org/00000001-6033-6516

3 Дубневич Павло Богданович - аспірант кафедри екологічної економіки. Національний лісотехнічний університет України, вул. Генерала Чупринки, 103, м. Львів, 79057, Україна. Тел.: +38-093-024-05-57. E-mail: paul.dubnevych@gmail.com ORCID: https:// orcid.org/0000-0001-6077-1462
} 
ревагою використання енергії деревної біомаси $є$ ї̈ приналежність до відновних ресурсів. Лісовий сектор економіки має значний потенціал відходів деревини, яка може бути використана в енергетичних цілях. Вивчення потенційно доступних обсягів біомаси для енергетичних потреб, зокрема деревної, може стати важливим науковим підгрунтям для вирішення цієї проблеми. Зростання виробництва відновлюваної енергії зумовлює необхідність пошуку компромісів щодо виробництва енергії, продуктів харчування та кормів для тваринництва (Schmidt et al., 2012), а також інших аспектів, на які воно впливає, зокрема, кількість та якість води (Lautenbach, 2012). Аналіз енергетичного потенціалу з урахуванням пошуку компромісів конфліктних інтересів здійснювався також і в галузі сільського господарства (Bryan, King \& Wang, 2010, Lewandowski et al., 2006, Koschke et al., 2013).

Переваги використання альтернативних джерел енергії описані багатьма дослідниками, проте, питання стосовно того, який обсяг деревної біомаси в Україні може бути використано для енергетичних потреб, залишається дискусійним. Зокрема, Aliyeva (2016) наводить загальні переваги використання альтернативних джерел енергіï, a Klimchuk (2012) фокусує увагу на перевагах та недоліках використання енергії сонця, вітру, біомаси сільського господарства та малої гідроенергетики.

За результатами досліджень біоенергетичної асоціації України, потенціал деревної біомаси в Україні, яка може бути використана в енергетичних цілях, є значним. Встановлено, що обсягів біомаси в Україні достатньо, щоб замінити весь імпорт газу і вугілля (15 days of bioenergy in Ukraine, 2019). В Україні опрацьовано термінологічно-поняттєвий інструментарій i теоретико-методологічну базу для розроблення методики оцінювання енергетичного потенціалу деревної біомаси лісів, що опирається на концептуальні засади сталого розвитку (Vasylyshyn, 2017). Водночас значними $є$ прогалини у сфері формування відповідної секторальної політики. Процес отримання деревної енергії та використання деревної біомаси в енергетичних цілях не регулюється інструментами біоенергетичної політики в Україні. Енергетична стратегія України на період до 2035 р. передбачає перехід на відновлювальні джерела енергії, розглядає деревну біомасу як один із варіантів отримання паливної енергії, але не описує чітких дій та заходів регулювання у біоенергетичній сфері (Energy Strategy, 2017). Законодавство фактично не трактує цю сферу діяльності як галузь альтернативної енергетики. Чинна модель та система доступу до лісової біомаси має низку критичних недоліків для біоенергетичного ринку - відсутність прозорого ринку для компанійзаготівельників, відсутність прозорого ринку технічної деревини, залежність ринку біоенергетичної сировини від стратегічного підходу до управління лісовими ресурсами (Vorobey, Gydz, 2017).

В Україні не існує розроблених засад біоенергетичної політики, а також принципів та інструмен- тів, які б регулювали процес використання деревного біопалива в енергетичних цілях з урахуванням результатів оцінювання наявного потенціалу біомаси та вимог досягнення сталого розвитку.

Об'єкти та методика дослідження. Об'єкт дослідження - паливна деревина, яка може бути використана в енергетичних цілях в контексті біоенергетичної політики України. Предмет досліджень - еколого-економічні аспекти формування біоенергетичної політики 3 акцентуванням уваги на деревну біомасу, яка може бути використана в енергетичних цілях. Мета роботи - розроблення теоретико-методологічних основ біоенергетичної політики, яка регулюватиме процес використання паливної деревини в енергетичних цілях.

Основними завданнями $є$ розгляд та аналіз деревного біопалива як альтернативного джерела енергії, його частки у структурі інших видів біомаси, а також формулювання самого поняття біоенергетичної політики, яка регулює процес отримання деревної енергії. Методика дослідження грунтується на аналізі літературних джерел, матеріалів статистичної звітності, термінологічної і нормативноправової бази, яка впливає на формування біоенергетичної політики 3 акцентуванням уваги на деревині як ефективному енергетичному ресурсі.

Результати досліджень. Виділено такі критеpiï ефективності використання деревної енергії: більша енергоконцентрація кінцевого продукту порівняно з вихідним, що підвищує його транспортабельність і переводить 3 категорії місцевих видів палива у категорію кондиційних експортних; значні масштаби виробничих процесів і пов'язана 3 цим їхня менша питома енергоємність; менший негативний вплив на довкілля промисловими відходами деревини (Maksymiv, 2016). Ці критерії стосуються здебільшого готової паливно-енергетичної продукції (брикетів, пелет). Вагоме значення має використання необроблених відходів деревини (дров), що $\epsilon$ важливим і єдиним паливним ресурсом для більшості населення сільських територій України. На домашні господарства припадає близько $65 \%$ обсягу використання деревної енергії (Maksymiv, 2016). Недостатня розгалуженість гілок газопроводів, географічні умови та історична ментальність населення спонукають до активного використання саме цього виду палива.

Для сталого розвитку біоенергетичної галузі України необхідно сформувати біоенергетичну політику як, наприклад, у Швейцарії, Фінляндії та низці інших країн $€ C$, де вона функціонує аналогічно до лісової та екологічної політики. Передбачено низку законодавчих актів, які регулюють процес використання деревини для енергетичних потреб, чітко визначений обсяг та біоенергетичний потенціал, а також, санкції за порушення норм законодавства та нераціональне використання біоенергетичного ресурсу. У Швейцарії розроблена спеціальна методика, яка дає змогу оцінювати цей потенціал як у розрізі кантонів, так і для країни загалом (Burg et al., 2017). 
Засади біоенергетичної політики в Україні не сформульовані, не обгрунтовані іiі пріоритети, принципи та інструменти. Однак окремі іiі аспекти зазнають впливу лісової та екологічної політики. За визначенням Synyakevich (2011), екологічна політика - це сукупність принципів та інструментів, які використовуються національними й наднаціональними органами, політичними партіями й громадськими організаціями для досягнення мети екологічної політики в галузі відтворення, охорони та використання природних ресурсів. За Dubovich (2018), екологічна політика - це система правових заходів, спрямованих на організаційну та регулятивно-контрольну діяльність держави i/aбо міжнародних організацій щодо охорони та оздоровлення навколишнього природного середовища, раціонального використання й відтворення природних ресурсів, забезпечення екологічної безпеки та належної життєдіяльності громадян. Лісова політика - це сукупність принципів та інструментів, які використовують національні і наднаціональні органи, політичні партії і громадські організації для відстоювання своїх інтересів у галузі відтворення, охорони і використання лісових ресурсів (Synyakevich, 2013).

На основі визначень лісової та екологічної політик, можна сформулювати визначення біоенергетичної політики як сукупності принципів та інструментів, які використовуються державними органами влади, громадськими i міжнародними організаціями та іншими зацікавленими сторонами для здійснення організаційної і регулятивноконтрольної діяльності стосовно процесу використання біомаси для енергетичних потреб, способів їі отримання, переробки та використання на засадах енергоефективності відповідно до цілей сталого розвитку.

Біоенергетична політика України у сфері використання деревної біомаси, отримання деревного біопалива має містити ті самі засадничі риси, що i біоенергетична політика будь-якої держави, тобто бути спрямованою на контроль та регулювання процесу використання деревини для енергетичних потреб, способів її отримання, перероблення у формі різних видів продукції (напр., паливних брикетів та пелет), використання і реалізацію паливної продукції, включаючи експорт.

Взаємозв'язок екологічної, лісової та біоенергетичної політик полягає в тому, що остання $є$ похідною від екологічної та лісової, оскільки регулює використання деревної біомаси для енергетичних потреб з урахуванням екологічних обмежень, в той час як лісова політика спрямована на контроль та регулювання безпосередньо процесу використання, охорони та відтворення лісових ресурсів, а екологічна - на охорону довкілля та забезпечення екологічної складової добробуту для населення. Саме вона пропонує інструменти для регулювання та контролю процесу повторного використання деревини 3 метою отримання енергетичного продукту і водночас зменшення захаращення лісосік відходами лісозаготівлі, дає змогу встановити недоцільність спалювання порубочних решток на лісосіках i, як наслідок, частково забезпечує потреби населення в енергетичних ресурсах.

Створення законодавчо-нормативної бази на основі використання зарубіжного досвіду та оцінки потенціалу деревної біомаси в Україні, яка може бути використана в енергетичних цілях, $€$ головним завданням біоенергетичної політики України. Біоенергетична політика повинна бути спрямованою на досягнення цілей сталого розвитку шляхом застосування відповідних стратегій та інструментів i систематично оцінюватися за допомогою системи індикаторів. Економічна ефективність застосування норм біоенергетичної політики очевидна: збільшення ланцюга доданої вартості від переробки деревини, забезпечення додаткових робочих місць, можливість отримання додаткового доходу на мікро- та макроекономічних рівнях.

Еколого-економічні передумови біоенергетичного використання деревини. Основу рішень біоенергетичної політики України у сфері використання деревної біомаси визначає аналіз можливостей заготівлі деревного біопалива (Possibilities of harvesting fuelwood, 2018). Так, у 2017 р. заготівля ліквідної деревини в Україні склала 19,60 млн м³ т.ч. дров для опалення $-6,92 \mathrm{млн} \mathrm{м}{ }^{3}$. Вже з $2000 \mathrm{p}$. спостережено тенденцію поступового збільшення обсягів заготівлі ліквідної деревини та дров для опалення.

Проаналізуємо динаміку заготівлі ліквідної деревини та самозаготівлі дров домогосподарствами в Україні (рис. 1). За результатами аналізу, з 2014 р. самозаготівля дров домогосподарствами перевищувала обсяг заготівлі паливних дров лісогосподарськими підприємствами. Прогнозна оцінка необхідних обсягів заготівлі окремих видів деревного палива постійними лісокористувачами впродовж 2018-2035 рр. грунтується на ключових показниках «Енергетичної стратегії України» на період до 2035 року, а також на існуючих статистичних даних та низці експертних оцінок і припущень. Згідно «Енергетичної стратегії», прогнозований обсяг біомаси, біопалива та відходів у загальному первинному постачання енергії становитиме: 2020 рік 4 млн т нафтового еквіваленту (н.е.), 2025 рік 6 млн т н.е., 2030 рік -8 млн т н.е., 2035 рік 11 млн т н.е., тобто, зросте протягом 2015-2035 pр. у 5,2 paza (Energy Strategy, 2017).

Частка деревної біомаси згідно прогнозування становить близько $90 \%$ від загального обсягу біомаси: 2020 рік - 3,6 млн т н.е., 2025 рік 5,4 млн т н.е., 2030 рік - 7,2 млн т н.е., 2035 рік 9,9 млн т н.е.

Питому вагу деревного біопалива у структурі загального постачання первинної енергії України, згідно енергетичної стратегії на період до 2035 року, представлено на рис. 2 (Possibilities of harvesting wood fuel in the forests of Ukraine, 2018; Energy Strategy, 2017). 


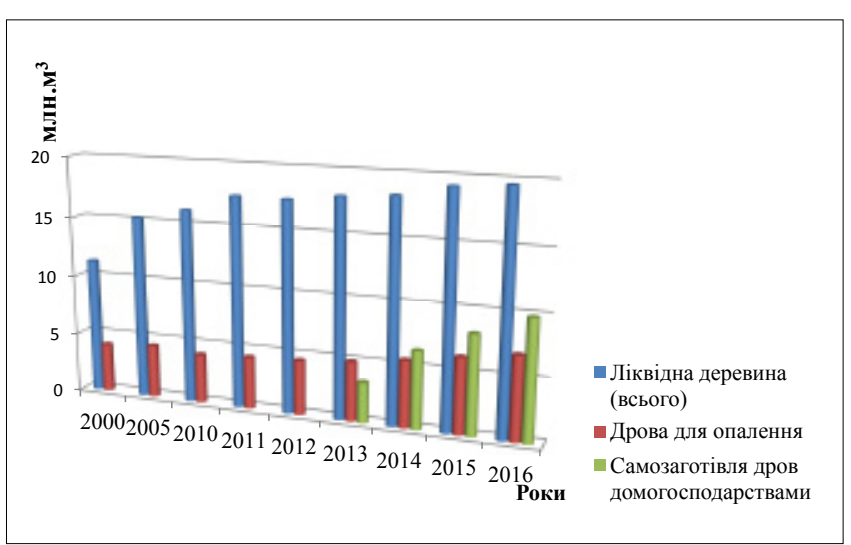

Рис. 1. Обсяги заготівлі ліквідної деревини та самозаготівля дров домогосподарствами в Україні (Geletukha et al., 2018)

Особливостями структури енергетичного потенціалу біомаси в Україні є відносна обмеженість деревних ресурсів (близько 2,6 млн т н.е./рік за загального потенціалу біомаси 21,2 млн т н.е./piк, за даними 2016 р.) та наявність значного обсягу біомаси сільськогосподарського походження (Possibilities of harvesting fuelwood, 2018). Вагому частину дров для опалення отримують шляхом самозаготівлі домогосподарствами. Це пов'язано з відносно високою вартістю дров для опалення, яку заготовляють місцеві лісгоспи. Обсяг самозаготівлі у 2015 р. оцінений експертами Біоенергетичної асоціації України у 4,38 млн м ${ }^{3}$. Припускається, що він зменшиться до 2,20 млн м ${ }^{3}$ у 2035 році за рахунок розвитку цивілізованого ринку біопалива.

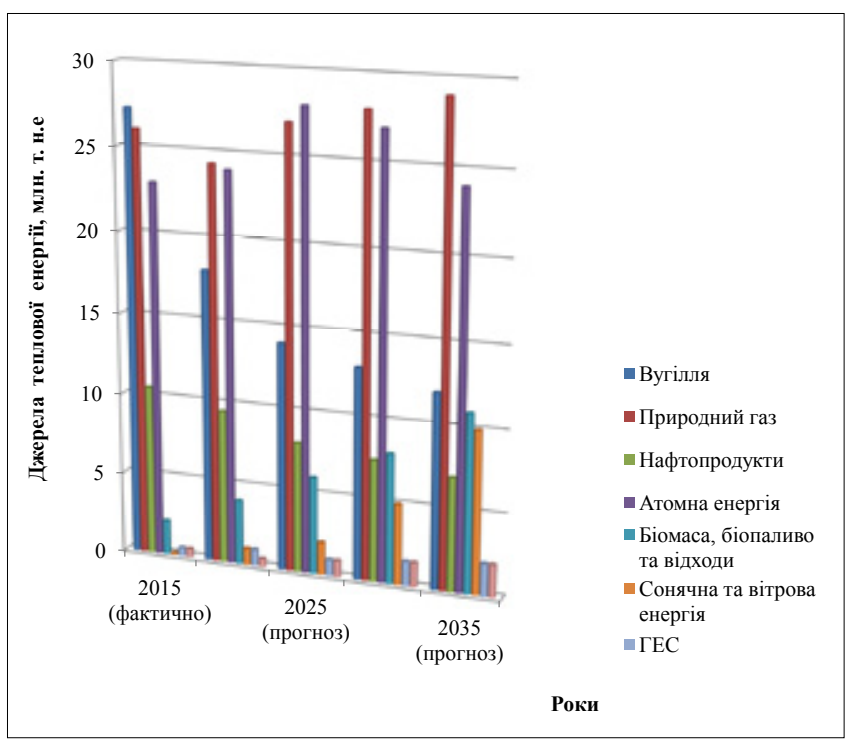

Рис. 2. Питома вага деревного біопалива у структурі загального постачання первинної енергії України, згідно енергетичної стратегії на період до 2035 року

За зазначеного підходу та припущень, частка деревного палива у загальній структурі твердого біопалива становитиме: 3 урахуванням самозаготівлі дров населенням (домогосподарствами) $2,35$ млн т н.е. (або 12,36 млн м $)$ у 2018 р. із збільшенням до 2,85 млн т н.е. (або 15,00 млн м³) у
2035 р.; без урахування самозаготівлі дров населенням (домогосподарствами) - 1,76 млн т н.е. (або 8,16 млн м ${ }^{3}$ ) у 2018 р. із збільшенням до 2,54 млн т н.е. (або 12,80 млн м ${ }^{3}$ ) у 2035 році.

Питому вагу деревного біопалива у структурі використання інших видів біомаси до 2035 р. (враховуючи прогнозну оцінку) представлено на рис. 3.

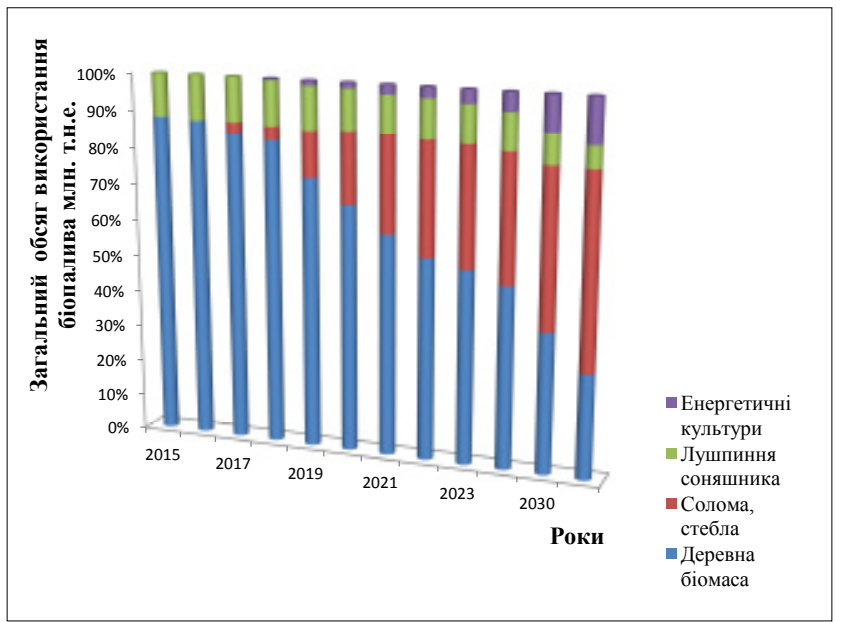

Рис. 3. Питома вага деревного біопалива у структурі використання інших видів біомаси до 2035 року (враховуючи прогнозну оцінку на основі Geletukha et al., 2018)

Для забезпечення використання зазначених обсягів деревного палива (без врахування самозаготівлі дров населенням) обсяг його заготівлі постійними лісокористувачами має складати не менше 8,30 млн м ${ }^{3}$ у 2018 р. (у тому числі дрова - не менше 7,2 млн м ${ }^{3}$, тріска - 1,1 млн м ${ }^{3}$ ) із збільшенням до 13 млн м ${ }^{3}$ у 2035 р. (у тому числі дрова - не менше 9,5 млн м ${ }^{3}$, тріска - 3,5 млн м ${ }^{3}$ ). У майбутній перспективі загальний обсяг використання деревного палива буде зростати до 2030 р., пізніше очікується спад разом із обсягом самозаготівлі дров населенням. Поряд з цим, спостерігається збільшення обсягу заготівлі тріски постійними лісокористувачами та загального обсягу використання без врахування самозаготівлі дров населенням. Варто зазначити, що існують два основних джерела отримання деревного біопалива: а) лісова деревна біомаса: відходи на лісосіках, дрова для опалення, які заготовляють державні лісогосподарські підприємства, неліквідна деревина, яка не може бути використана в процесі обробки через низькі технічні властивості; б) відходи деревообробки: технологічна тріска, тирса, що використовуються як паливо, а також $є$ сировиною для виробництва пелет i деревних брикетів.

У першому випадку широко для опалення використовують дрова, тоді як лісозаготівельні відходи переважно залишають безпосередньо на лісосіках.

У зв'язку з цим, назріла необхідність у формуванні біоенергетичної політики, яку ми трактуємо як сукупність принципів та інструментів, які використовують державні органи влади, міжнародні і громадські організації та інші стейкхолдери 
для здійснення організаційної та регулятивноконтрольної діяльності стосовно отримання, переробки та використання біомаси для енергетичних потреб. Не менш важливим аспектом є прийняття відповідних законодавчих актів, які допоможуть розвинути біоенергетичну галузь у сфері використання деревної біомаси в Україні.

Зокрема важливим регуляторним інструментом біоенергетичної політики може стати сертифікація паливно-енергетичної продукції згідно європейських стандартів сталої біоенергетики (Soloviy et al., 2019).

Висновки. В Україні не сформульовано політику та відповідні інструменти, які повинні регулювати процес використання деревини в енергетичних цілях. Основою для їх розробки може стати досвід Швейцарії та країн $€ C$, а також нові ініціативи сталої політики у сфері біоенергетики (A new EU sustainable bioenergy policy, 2020).

Основою прогнозування біоенергетичної політики $є$ аналіз можливостей заготівлі деревного палива в лісах України з урахуванням суспільних потреб та екологічних обмежень. Деревна біомаса посідає перше місце серед інших видів біомаси, які використовують в енергетичних цілях в Україні. Аналіз можливостей заготівлі деревного палива в лісах України підтверджує, що потенціал деревної біомаси, яка може бути використана для отримання енергії $є$ значним, i біоенергетична галузь економіки України у сфері використання деревного біопалива має перспективи для розвитку. Значну частку у структурі деревної біомаси становлять відходи від лісопилення та виробництва меблів.

Важливим завданням політики є створення умов для формування прозорого ринку біоенергетики, для якого істотне значення мають політики у сферах регіонального розвитку, енергетики та енергоефективності, управління лісовими ресурсами та розвиток інструментів державно-приватного партнерства (Vorobey, Gydz, 2017). Застосування принципів та інструментів біоенергетичної політики, запровадження європейських стандартів у сфері сертифікації паливно-енергетичної продукції стимулюватиме розвиток біоенергетичної галузі в Україні та використання деревини як енергетичного ресурсу у відповідності з принципами сталого розвитку.

\section{References}

A new EU sustainable bioenergy policy (2020). Proposal to regulate bioenergy production and use in the EU's renewable energy policy framework $2020-2030$. Available at: http://www.birdlife.org/sites/default/ files/a_new_eu_sustainable_bionenergy_policy_ 2016.pdf

Aliyeva, O., \& Larina, M. (2016). Renewable Energy: Benefits for All. Heinrich Boll Stiftung. Available online: https://ua.boell.org/en/2016/09/29/ vidnovlyuvana-energetika-perevagi-dlya-vsih.
Bryan, B.A., King, D., \& Wang, E. (2010). Biofuels agriculture: Landscape-scale trade-offs between fuel, economics, carbon, energy, food, and fiber. GCB Bioenergy, 2 (6), 330-345. https://doi.org/10.1111/ j.1757-1707.2010.01056.x

Burg, V., Bowman, G., Erni, M., Lemm, R., \& Thees, O. (2017). Analyzing the potential of domestic biomass resources for the energy transition in Switzerland. Biomass and bioenergy, 111, 60-69. https://doi. org/10.1016/j.biombioe.2018.02.007

Dubovich, I.A. (2018). Environmental policy. Bucharest: RCR EDITORIAL

Energy Strategy of Ukraine for the period up to 2035 «Safety, Energy Efficiency, Competitiveness». (2017). Order of the Cabinet of Ministers of Ukraine dated August 18. No. 605-p.: https://de. com.ua/uploads/0/1703-EnergyStratagy 2030.pdf (in Ukrainian).

15 Days of bioenergy in Ukraine - 15 posters with the most interesting facts about the industry (2019). Bioenergy Association of Ukraine. http://www. uabio.org/infographics/4287-ukrainian-bioenergyday-campaign (in Ukrainian).

Klimchuk, S.A. (2012). Alternative energy: current state and prospects for development Investments. Innovation in Economics, 24, 1-7. http://chtei-knteu. cv.ua/herald/content/download/archive/2012/v2/NV2012-v2 20.pdf (in Ukrainian).

Koschke, L., Fürst, C., Lorenz, M., Witt, A., Frank, S., \& Makeschin, F. (2013). The integration of crop rotation and tillage practices in the assessment of ecosystem services provision at the regional scale. Ecological Indicators, 32, 157-171. https://doi. org/10.1016/j.ecolind.2013.03.008

Lautenbach, S., Volk, M., Strauch, M., Whittaker, G., \& Seppelt, R. (2012). Quantifying trade-offs between bioenergy production, food production, water quality and water quantity aspects in a German case study. In R. Seppelt, A. A. Voinov, S. Lange, D. Bankamp, (Eds.), Proceedings of the International Congress on Environmental Modelling and Software: Managing Resources of a Limited Planet, Sixth Biennial Meeting, Leipzig, Germany, 1-5 July 2012; Available online: http://www.iemss.org/society/index.php/ iemss-2012-proceedings.

Lewandowski, I., Weger, J., van Hooijdonk, A., Havlickova, K., van Dam, J., \& Faaij, A. (2006). The potential biomass for energy production in the Czech Republic. Biomass Bioenergy, 30 (5), 405-421.

Maksymiv, L. I., Klymovych, V.P., \& Zagvoyska L.D. (2016). Using the energy potential of wood: ecological and economic dimension. Proceedings of the Forestry Academy of Sciences of Ukraine, 14, 244-251. https://doi.org/10.15421/411633 (in Ukrainian).

Geletukha, G. G., Zhelyesna, T.A., Pastukh, A. V., \& Dragnev, S.V. (2018). Analytical note BAU №19. Bioenergy Association of Ukraine. Available online: http://uabio.org/img/files/docs/position-paper-uabio19-ua.pdf (in Ukrainian). 
Schmidt, J., Schönhart, M., Biberacher, M., Guggenberger, T., Hausl, S., Kalt, G. ... Schmid, E. (2012). Regional energy autarky: Potentials, costs and consequences for an Austrian region. Energy Policy, 47 (C), 211-221. https://doi.org/10.1016/j. enpol.2012.04.059

Soloviy, I., Melnykovych, M., Gurung, A.B., Hewitt, R. J., Maksymiv, L., Brang P., Meessen, H., \& Kaflyk, M. (2019). Innovation in the use of wood energy in the Ukrainian Carpathians: Opportunities and threats for rural communities. Forest Policy and Economics, 104, 160-169. https://doi.org/10.1016/j. forpol.2019.05.001

Synyakevych, I.M. (2011). Environmental Policy: A Strategy to Overcome Global Environmental Threats. Lviv: ZUCTS.

Synyakevich, I.M., Deineka A.M., \& Soloviy I.P. (2013). Forestry Politics. Kyiv: Knowledge

Vasylyshyn, R.D. (2017). Theoretical and methodological bases the energy potential of woody biomass in forests estimation on the principles of sustainable forest management. Proceedings of the Forestry Academy of Sciences of Ukraine , 15, 82-89. https://doi.org/10.15421/411710 (in Ukrainian).

Vorobey, V., Gydz, N. (2017). State of the bioenergy market in 9 regions of Ukraine (Volyn, Zhytomyr, Transcarpathian, Ivano-Frankivsk, Lviv, Rivne, Ternopil, Khmelnytsky, Chernivtsi). Analytical research. Lviv: Available online: http://www.ppv.net. ua/uploads/work_attachments/Western_Ukrainian_ Bioenergy_Market_Study_2017.pdf (in Ükrainian).

\section{Использование древесины в фокусе внимания биоэнергетической политики Украины}

\section{И.П. Соловий' , М.С. Кафлык², П.Б.Дубневич}

Древесное биотопливо является одним из основных видов альтернативной энергии в Украине и в то же время древесная биомасса - один из самых дешевых энергетических ресурсов Украины. До-

\footnotetext{
Соловий Игорь Павлович - академик Лесной академии наук Украины, вице-президент ЛАН Украины, доктор экономических наук, профессор кафедры экологической экономики. Национальный лесотехнический университет Украины, ул. Генерала Чупрынки, 103, г. Львов, 79057, Украина. Тел.: 032-287-03-88, +38-097-284-08-81. E-mail: soloviy@yahoo. co.uk ORCID: https://orcid.org/0000-0001-5885-6264.

Кафлик Мария Степановна - аспирант кафедры экологической экономики. Национальный лесотехнический университет Украины, ул. Генерала Чупрынки, 103, Львов, 79057, Украина. Тел.: 097-443-13-95. E-mail: andruschakevich1994@i.ua ORCID: https://orcid.org/0000-0001-6033-6516

Дубневич Павло Богданович - аспирант кафедры экологической экономики. Национальный лесотехнический университет Украины, ул. Генерала Чупрынки, 103, Львов, 79057, Украина. Тел.: 093-024-05-57 E-mail: paul.dubnevych@gmail.com ORCID: https://orcid.org/0000-0001-6077-1462
}

казано, что ее объем является достаточно весомым для обеспечения энергетических потребностей населения. Вместе с тем, значительный объем древесной биомассы в Украине, который может быть использован в энергетических целях, не задействован, в частности, лесосечные отходы. Использование отходов заготовки и обработки древесины в качестве топлива является экологически и экономически эффективным решением. Актуальность внедрения биоэнергетической политики, которая будет регулировать процесс вторичного использования древесины очевидна, поскольку в Украине нет четких законодательных норм и положений, регулирующих биоэнергетическую сферу, кроме «Энергетической стратегии Украины до 2035 года». Установлено, что использование потенциала отходов древесины с позиций экономики замкнутого цикла может внести весомый вклад в решение энергетической проблемы Украины. Использование древесной биомассы в энергетических целях не регулируется четкой и прозрачной биоэнергетической политикой и набором соответствующих инструментов. Энергетическая стратегия Украины на период до 2035 года рассматривает древесную биомассу как один из вариантов получения топливной энергии, но не описывает действия и меры относительно непосредственно самого процесса получения биоэнергии. Законодательная база Украины также считается несовершенной, поскольку хотя и рассматривает древесную биомассу как источник альтернативной (возобновляемой) энергии, но не принимает во внимание все ее особенности как отдельного вида топлива. В связи с этим, уместно перенять опыт других стран по широкому и разностороннему использованию древесной биомассы в энергетических целях. Создание законодательной базы на основе использования зарубежного опыта и оценки потенциала древесной биомассы в Украине, которая может быть использована в энергетических целях, является главной задачей политики биоэнергетики Украины.

Одним из важных источников получения топливной древесины являются отходы лесопильного и мебельного производства. Доказано, что объемов биомассы в Украине достаточно, чтобы заменить импорт газа и угля. Развитие биоэнергетики должно охватывать вопросы получения энергии из лесосечных отходов, отходов деревообработки и неликвидных остатков, а также из энергетических плантаций.

В Швеции около $60 \%$ энергии для отопления жилья получают вследствие сгорания биомассы, в то время как в Украине только 9\%. Учет социальных и экологических ограничений при определении количества биомассы, которая может быть изъята из леса, обеспечивая эколого-экономическое обоснование всего процесса сбора, сортировки и переработки древесной биомассы, является важной составляющей достижения концепции устойчивого развития лесного сектора. Важным заданием является разработка набора инструментов 
и региональных стратегий биоэнергетической политики.

Ключевые слова: древесная биомасса; биотопливо; возобновляемая энергетика; биоэнергетический потенциал; лесной сектор; биоэнергетическая политика.

\section{Fuel wood usage in a focus of bioenergy policy of Ukraine}

\section{Soloviy ${ }^{1}$, M. Kaflyk ${ }^{2}$, P. Dubnevych ${ }^{3}$}

Wood as form of biomass is one of the main types of alternative energy in Ukraine. At the same time, wood biomass is one of the cheapest energy resources. It has been proved that its volume potential can be sufficient to meet the energy needs of the population. It is found that a significant amount of wood biomass in Ukraine, which can be used for energy purposes, is not yet used, particularly wood residuals in forest stands. The use of wood and wood residuals as fuel is an environmentally and cost-effective solution. However to meet sustainability goals some social and environmental limitations should be taken into account. The urgency of implementing a bioenergy policy for governing the process of wood residuals and biomass use for energy purpose is obvious, since there are no clear legislative norms and regulations to stimulate the bioenergy sector development in Ukraine, except for the "Energy Strategy of Ukraine until 2035". Fuel wood is one of the main types of bioenergy in Ukraine. It is found that sustainable utilization of wood residuals

Ihor Soloviy - Full Member of the Forestry Academy of Sciences of Ukraine, vice-president of the Ukrainian Forestry Academy of Sciences, Doctor of Economic Sciences, Professor of the Department of Ecological Economics. Ukrainian National Forestry University.103 General Chuprynka st., Lviv, 79057, Ukraine. Tel.: 032-287-03-88, + 38-097-284-08-81. E-mail:soloviy@yahoo. co.uk ORCID: https://orcid.org/0000-0001-5885-6264.

2 Maria Kaflyk - Postgraduate Student of the Department of Ecological Economics. Ukrainian National Forestry University, 103 General Chuprynky Str., Lviv, 79057, Ukraine. Tel.: 097-44313-95. Email: andruschakevich1994@i.ua ORCID: https://orcid. org/0000-0001-6033-6516

Pavlo Dubnevych - Postgraduate Student of the Department of Ecological Economics. Ukrainian National Forestry University, 103 General Chuprynky Str., Lviv, 79057, Ukraine. Tel.: 093-0240557. Email: paul.dubnevych@gmail.com ORCID: https://orcid. org/0000-0001-6077-1462 potential would contribute to the circular economy and at the same time can make a significant contribution to solving energy dependency from suppliers outside Ukraine.

The process of obtaining wood energy and using wood biomass for energy purposes is not governed by clear and transparent bioenergy policy and set of instruments in Ukraine. Ukraine's energy strategy for the period until 2035 envisages the transition to renewable energy sources, considers wood biomass as one of the options for obtaining fuel energy, but does not describe actions and regulation measures in bioenergy. The legislation is also seen as imperfect as it does not actually treat this wood biomass as an alternative (renewable) energy.

Creating a legislative framework based on the use of foreign experience and the assessment of the potential of wood biomass in Ukraine, which can be used for energy purposes, is the main task of Ukraine's bioenergy policy. Bioenergy policies should be aimed to achieving the sustainable development goals through the use of appropriate strategies and instruments and systematically assessed through a system of indicators. The main problem with the use of fuel wood is the lack of a legal framework governing its production and use. In this regard, it is appropriate to draw on the experience of other countries in the use of wood biomass for energy purposes. It is found that the main source of fuel wood is sawmill and furniture waste. It has been proven that biomass in Ukraine is sufficient to replace all gas and coal imports. The term "bioenergy" has been found not to refer to deforestation. It is about the use of wood waste and illiquid residues. In Sweden, $60 \%$ of heat is produced from biomass, however, in Ukraine only $9 \%$. Taking into account the social and environmental constraints in determining the amount of biomass that can be removed from the forest, providing an ecological and economic justification for the entire process of harvesting, sorting and processing of biomass is an important component of achieving the concept of sustainable development of the forest sector. The main problem with the use of fuel wood is the lack of a legal framework governing its production and use. In this regard, it is appropriate to take into account the experience of other countries in the use of wood biomass for energy purposes. Therefore the most important task is to develop regional strategies and a set of bioenergy policy instruments.

Key words: wood biomass; biofuels; renewable energy; bioenergy potential; forest sector; bioenergy policy. 